\title{
Sexual reproduction in the Mediterranean solitary coral Balanophyllia europaea (Scleractinia, Dendrophylliidae)
}

\author{
Stefano Goffredo*, Silvia Arnone, Francesco Zaccanti
}

Dipartimento di Biologia Evoluzionistica Sperimentale, Università degli Studi di Bologna, via F. Selmi 3, 40126 Bologna, Italy

\begin{abstract}
Balanophyllia europaea (Risso, 1826) is a common scleractinian coral living on subtidal rocky substrates in the Mediterranean Sea. The annual sexual reproductive cycle of this species is studied in specimens from an area near Leghorn (Tuscany, Italy). This study represents the first report of a reproductive cycle in a Mediterranean scleractinian coral. B. europaea is a simultaneous hermaphrodite and brooder. Polyp size at sexual maturity occurs at approximately 3 yr of age (6 to $10 \mathrm{~mm}$ maximum oral disc diameter). Observation of hermaphroditic polyps shows several significant differences in the distribution of spermaries and oocytes along the oral-aboral axis. Mean distance of spermaries from the oral pole is less than that of oocytes. Also, large mature spermaries tend to line up towards the mouth, while large mature oocytes tend to line up towards the polyp base. This differential gamete distribution could result in a barrier to self-fertilization, as it reduces encounters between gametes of the opposite sex produced by the same individual. Testes require $1 \mathrm{yr}$ to reach maturity with a maximum spermary diameter of $500 \mu \mathrm{m}$. Oogenesis lasts 2 yr with a maximum oocyte diameter of $1400 \mu \mathrm{m}$. Fecundity varies significantly with polyp size. The rate of gonadal development increases significantly during January and February, fertilization takes place in March to June and planulation in August and September. Released larvae have a maximum diameter of $2000 \mu \mathrm{m}$. The annual cycle of photoperiod and water temperature appear to coincide with the reproductive cycle in B. europaea.
\end{abstract}

KEY WORDS: Coral • Balanophyllia europaea • Reproduction · Gametogenesis · Fecundity · Mediterranean

\section{INTRODUCTION}

The studies hitherto conducted on the annual cycle of sexual reproduction in scleractinian corals refer almost exclusively to tropical and subtropical species (Fadlallah 1983b, Harrison \& Wallace 1990, Richmond \& Hunter 1990, Richmond 1997, Lam 2000), with few data on reproduction in temperate species (Stoddart \& Black 1985, Ward 1992, Beauchamp 1993, and references therein). In particular, for species living in the Mediterranean, information is available only from the 19th century, on Caryophyllia smithi, Astroides calycularis,

\footnotetext{
*E-mail: sgoff@tin.it
}

Balanophyllia regia, B. pruvoti and Cladopsammia rolandi (Lacaze-Duthiers 1873, 1897), and from the last few years on B. europaea (Goffredo \& Telò 1998, Goffredo et al. 2000).

Most scleractinians examined to date are hermaphroditic and reproduction is characterized by external fertilization and a 1 yr gametogenic cycle culminating in a short period during which germ cells are released (Oliver et al. 1988, Harrison \& Wallace 1990, Richmond \& Hunter 1990). Reproductive cycle regulation in these organisms has been associated with environmental factors (Harrison \& Wallace 1990). Some studies suggest that the annual reproductive cycle is mainly regulated by seasonal variations in water temperature and photoperiod (Giese \& Pearse 1974, Babcock et al. 1986,

() Inter-Research $2002 \cdot$ www.int-res.com 
Oliver et al. 1988, Harrison \& Wallace 1990, Soong 1991), but other studies do not support this link (Beauchamp 1993, Babcock et al. 1994, Fan \& Dai 1995). The period during which germ cells are released varies geographically (Harrison \& Wallace 1990, Richmond \& Hunter 1990); comparison of the timing of gamete release between localities within coral species may reveal population responses to different environmental conditions (Oliver et al. 1988, Harrison \& Wallace 1990, Babcock et al. 1994, Fan \& Dai 1995).

Many authors suggest that environmental factors may influence reproduction, because they act as longterm agents exerting selective pressure on the sexuality and reproductive mode of populations (Giese \& Pearse 1974, Bacci 1975, Rossi 1975, Loya 1976, Van Moorsel 1983, Szmant 1986, Tomascik \& Sander 1987, Shaw 1989, Fautin 1992, Ward 1992, Fan \& Dai 1995). Harrison (1985), however, suggests that sexual condition is a relatively constant feature within families, and defines Dendrophylliidae, the family to which Balanophyllia europaea belongs, as gonochoric. According to Harrison \& Wallace (1990), comparative studies on congeneric species presenting different types of sexuality are essential to an understanding of the extent to which environmental conditions affect the selection of reproductive strategies.

Dendrophylliidae is a cosmopolitan family with 153 living species belonging to 21 genera (D. S. Cairns pers. comm.). A total of $94 \%$ of dendrophylliid corals studied are gonochoric (Harrison 1985). Of 50 known species of Balanophyllia (Cairns 1977), reproductive modalities are known only for B. pruvoti at Marseilles, France (Lacaze-Duthiers 1897), B. elegans at Monterey Bay, California (Fadlallah \& Pearse 1982a, Beauchamp 1993) and B. europaea at Leghorn, Italy (Goffredo \& Telò 1998, Goffredo 1999, Goffredo et al. 2000). All are brooders; the first 2 species are gonochoric and the latter is hermaphroditic.

According to Schumacher \& Zibrowius (1985), Balanophyllia europaea is a solitary, non-constructional, zooxanthellate scleractinian coral that lives on rocky substrates in the Mediterranean Sea and off Spain's Atlantic coast (Zibrowius 1980, 1983, Aleem \& Aleem 1992). Owing to its symbiosis with zooxanthellae, this coral lives at 0 to $50 \mathrm{~m}$ depth (Zibrowius 1980), where it reaches population density peaks of about 100 individuals $\mathrm{m}^{-2}$ (Goffredo 1999). Congeneric azooxanthellate corals have been reported at depths of up to $1100 \mathrm{~m}$ (Cairns 1977).

In this paper, we describe the annual cycle of sexual reproduction in Balanophyllia europaea inhabiting the eastern Ligurian Sea, near the city of Leghorn, Italy. We examine the morphological and quantitative aspects of oogenesis and spermatogenesis, the location of male and female gametogenesis in hermaphroditic polyps, the relationship between gonadal growth and relevant environmental factors, and sexual maturity and fecundity in relation to polyp size.

\section{MATERIALS AND METHODS}

Sampling. Specimens of Balanophyllia europaea were collected at Calafuria (Leghorn; $43^{\circ} 28.4^{\prime} \mathrm{N}, 10^{\circ} 20^{\prime} \mathrm{E}$ ) during 15 sample periods from July 1997 to October 1998. The mean interval between samples was $32 \mathrm{~d}$ $(\mathrm{SD}=9)$. Samples were collected by SCUBA divers at a depth of 6.4 to $6.8 \mathrm{~m}$, where the population reaches its maximum density (Goffredo 1999). Water temperature was measured directly, and photoperiod was calculated from astronomical almanacs corresponding to the time period in which sample collection took place. Monthly samples of 20 specimens each included the full range of sizes found within the population (coral length 1 to $20 \mathrm{~mm}$ ) (Goffredo 1999). We measured the length $(L$, maximum oral disc diameter), width $(l$, minimum oral disc diameter) and height $(h$, distance between the oral and aboral disc) of each collected individual and calculated body volume $(V)$ using the formula $V=h \times(L / 2) \times(1 / 2) \times \pi$ (after Goffredo \& Telò 1998).

Histological and cytometric analysis. Polyps were fixed in Bouin's solution, decalcified using EDTA, dehydrated through a graded alcohol series, and embedded in paraffin; 7 to $10 \mu \mathrm{m}$ thick transverse sections were cut in an oral/aboral serial sequence and stained with hematoxilin and eosin. We took cytometric readings of the histological samples using a LEICA Q500IW for image analysis. Oocytes were not grouped into clear ovaries, thus oocytes were used as the unit of comparison with the male gonads (spermaries). Maximum and minimum diameter dimensions were measured in nucleated oocyte and spermary sections. We estimated the size of the reproductive elements by averaging the 2 diameter dimensions. Following previous methods (Beauchamp 1993, Kramarsky-Winter \& Loya 1998, Kruger \& Schleyer 1998, Glynn et al. 2000), spermaries were graded according to maturation stages that were distinguishable by morphological characteristics. We recorded the presence of embryos in the coelenteric cavity as well as their developmental stage according to Goffredo \& Telò (1998).

Gonadal index. Oocytes and spermaries were ellipsoidal in shape, leading us to estimate gonadal volume using the following formula: $V_{\mathrm{o}}=(4 / 3) \times \pi \times D / 2 \times\left(\frac{d}{2}\right)^{2}$, where $V_{\mathrm{o}}=$ oocyte or spermary volume, $D=$ maximum diameter and $d=$ minimum diameter. Total gonadal volume was calculated as the sum of spermary and oocytes volumes. A gonadal development index was 
calculated as the percentage of body volume occupied by the gonads (Hall \& Hughes 1996).

Size at sexual maturity and fecundity. In order to determine the minimum size at which specimens reached sexual maturity, we considered the length at which $50 \%$ of the specimens developed spermaries and oocytes (after Rinkevich \& Loya 1979, Bianchini et al. 1998, Yoneda et al. 1998, Oh \& Hartnoll 1999, Roa et al. 1999). We expressed fecundity as the number of mature oocytes per polyp per reproductive season. The formula we used to establish the number of mature oocytes in each polyp was: Fecundity $=(A \times B) / C$, where $A=$ length of the 'ovary' (based on the number of sections in which oocytes were found), $B=$ observed frequency of mature oocytes, and $C=$ the diameter of mature oocytes (after Kruger \& Schleyer 1998).

\section{RESULTS}

\section{Sexuality and reproductive mode}

Specimens of Balanophyllia europaea were observed to be simultaneous hermaphrodites and brooders; no gonochoric polyp has been observed. Size at sexual maturity ranged from 6 to $10 \mathrm{~mm}$ in length (Fig. 1).

\section{Spermaries and oocytes}

Spermaries were observed as groups of germ cells delimited by a mesoglear envelope (Fig. 2). Diameters varied from 20 to $500 \mu \mathrm{m}$. We identified 5 distinct developmental stages of spermaries containing: I, spermatogonia (Fig. 2A,B); II, spermatocytes surrounded by spermatogonia (Fig. 2A,C); III, spermatocytes (Fig. 2D); IV, spermatocytes peripherally and spermatids and sperm centrally (Fig. 2E,F); V, sperm (Fig. 2G,H).

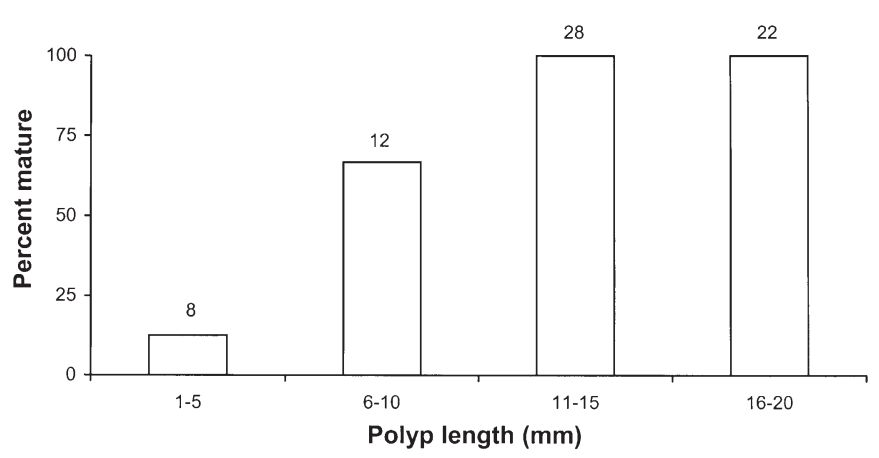

Fig. 1. Balanophyllia europaea. Percent of sexually mature individuals per size class sampled in Calafuria, southern Leghorn. Values above bars indicate the number of polyps sampled
The diameter of clearly identifiable oocytes varied from 20 to $1400 \mu \mathrm{m}$. Oocytes were found centrally in the mesenteries, surrounded by a mesoglear layer (Fig. 3). During the early stages of oogenesis, the centrally located nucleus was surrounded by a homogeneous cytoplasm (Fig. 3A-C) while in later stages the ' $U$ '-shaped nucleus was in the periphery of an heterogeneous ooplasm filled with small yolk plates (Fig. 3D-G). The nucleus/ooplasm size ratio decreased in later stages.

Distribution along the oral-aboral axis of the hermaphroditic polyp varied significantly between spermaries and oocytes (Fig. 4). Spermary size decreased with distance from the oral pole, while oocytes increased in size with distance from the oral pole. Even though spermary and oocyte spatial distributions overlapped, the mean distance of spermaries from the oral pole $(60.92 \%, \mathrm{SE}=0.15)$ was less than that of oocytes (68.34\%, SE =0.29; Student's $t$-test $\mathrm{p}<0.001$; Fig. 4).

\section{Annual sexual reproductive cycle}

Gonad size increased 5-fold in the winter months from January to February. Photoperiod increased during this time following the annual minimum (Fig. 5). In samples collected during these months, we observed 2 distinct oocyte stocks, one made of small cells (20 to $440 \mu \mathrm{m})$, the other of larger cells (440 to $1400 \mu \mathrm{m}$ ). We also observed an acceleration in spermatogenesis indicated by many spermaries at an intermediate stage of maturation (Fig. 6).

Fertilization occurred from March to June. Water temperature increased during this period following the annual minimum (Fig. 5). Large-sized oocytes disappeared in the samples collected during these months, while spermaries had reached full maturity; early and intermediate embryos were observed in the coelenteron (Fig. 6).

During the months immediately following fertilization (June to August), we observed a growth of smallsized oocyte stock, the recruitment of new oocytes, the beginning of spermary ripening and the incubation of embryos (Fig. 6).

Planulation took place between August and September. Water temperature began to decrease during this period following the annual peak (Fig. 5). During these months, mature embryos disappeared from the coelenteric cavity (Fig. 6).

\section{Mature oocyte size and fecundity}

Mature oocyte diameter ranged from 440 to $1400 \mu \mathrm{m}$ (Fig. 6). Polyp fecundity varied with body size (Fig. 7). 


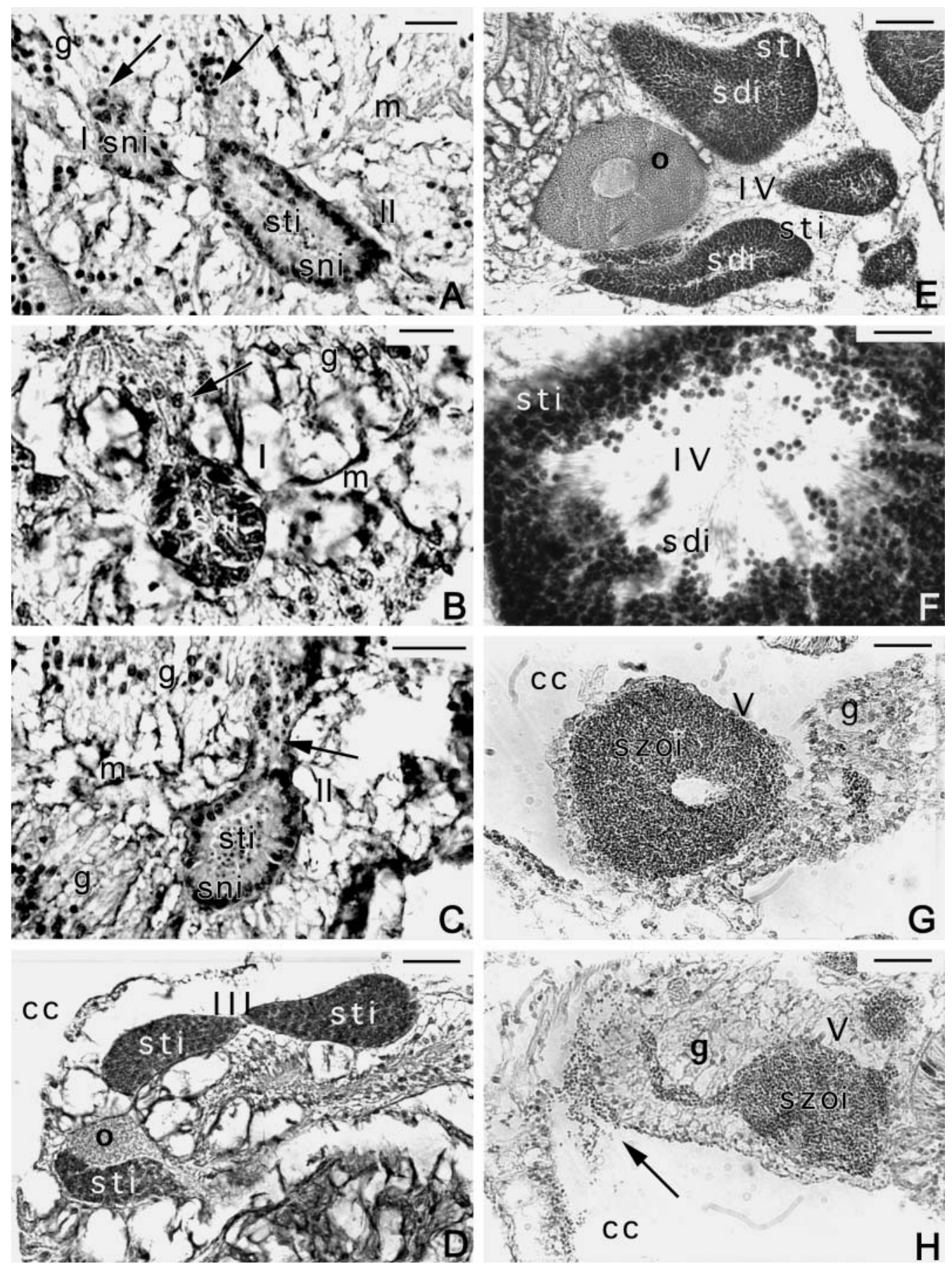

Fig. 2. Balanophyllia europaea. Stages of spermary maturation. (A) Early stages: spermaries originate from the migration of undifferentiated germ cells (arrows) that migrate from the gastrodermis to the mesoglea. Scale bar $=20 \mu$. (B) Stage I: the spermary is made up of a group of spermatogonia. Note the recruitment from the gastrodermis of undifferentiated germ cells (arrow). Scale bar $=20 \mu \mathrm{m}$. (C) Stage II: the spermary is made up of a layer of spermatogonia peripherally and of a group of spermatocytes centrally. Note the recruitment from the gastrodermis of undifferentiated germ cells (arrow). Scale bar $=20 \mu \mathrm{m}$. (D) Stage III: spermaries are made up of a mass of spermatocytes. Scale bar $=40 \mu \mathrm{m}$. (E) Stage IV: differentiated spermatids can be observed centrally; note that a cavity has formed. Scale bar $=60 \mu \mathrm{m}$. (F) Stage IV: spermatocytes are visible in the peripheral portion of the spermary; spermatids may be observed centrally with their tails projecting towards the central cavity. Scale bar $=20 \mu \mathrm{m}$. (G) Stage V: the spermary is made up of a mass of sperm. Scale bar $=40 \mu \mathrm{m}$. $(\mathrm{H})$ Stage V: sperm are released from the spermary and cross through the gastrodermis in order to reach the coelenteron (arrow). Scale bar $=40 \mu \mathrm{m}$. cc: coelenteric cavity; g: gastrodermis; m: mesoglea; o: oocyte; sdi: spermatids; sni: spermatogonia; sti: spermatocytes; szoi: sperm; I, II, III, IV, V: stage of spermary development (see 'Results') 


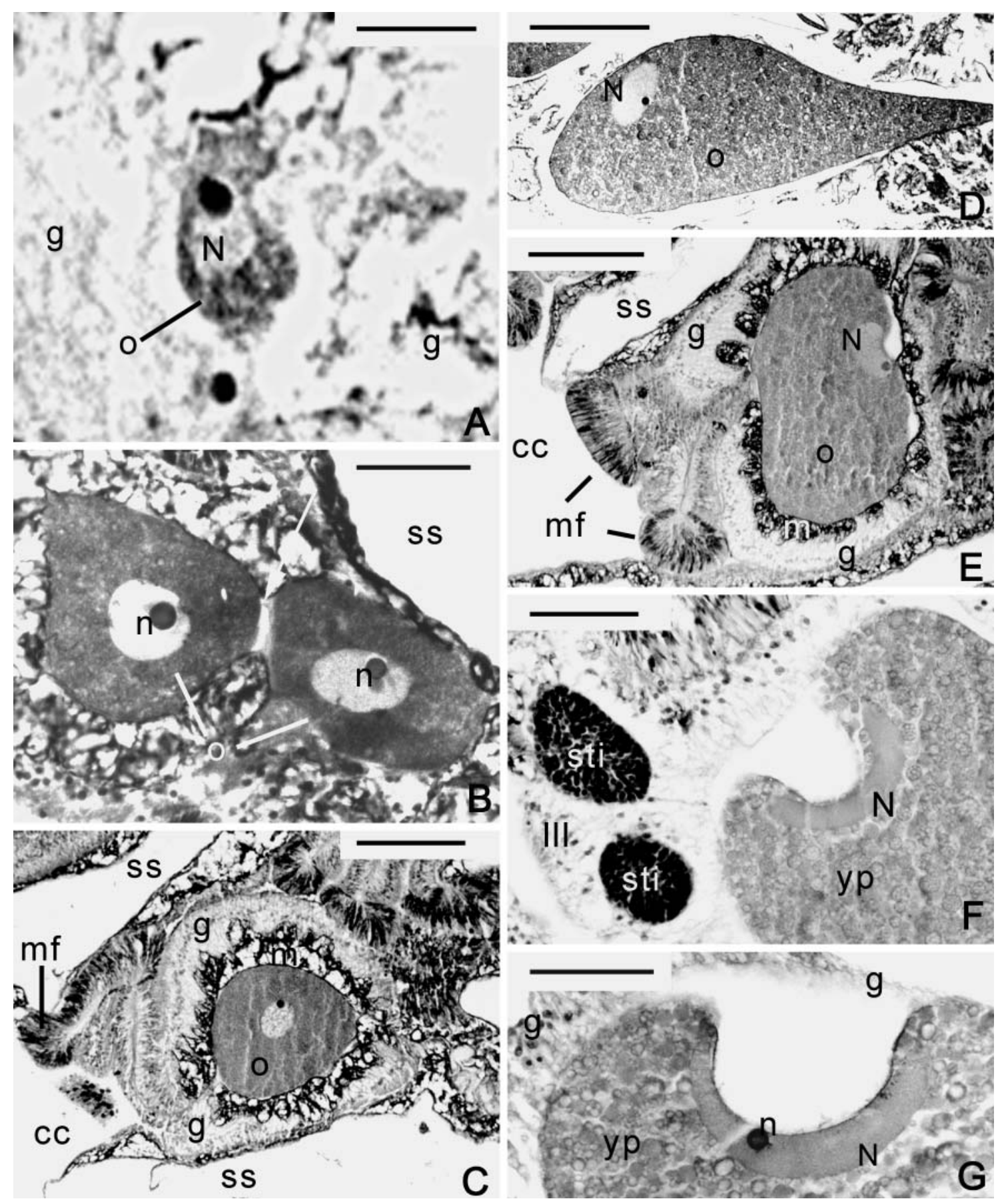

Fig. 3. Balanophyllia europaea oogenesis. (A-B) Early stages. (A) Small oocyte located in the gastrodermis characterized by a high nucleus:cytoplasm ratio. Scale bar $=20 \mu \mathrm{m}$. (B) Vitellogenic oocytes. The spherical nucleus is located centrally and contains a single nucleolus. Oocytes appear to be linked by an intercellular bridge (arrow). Scale bar $=30 \mu \mathrm{m}$. (C-D) Intermediate stages. (C) A medium-sized vitellogenic oocyte located in the central portion of the mesentery. The cytoplasm is still quite homogeneous. Scale bar $=140 \mu \mathrm{m}$. (D) Differentiation of the ooplasm has begun as well as the nucleus' migration towards the peripheral portion of the cell. Scale bar $=70 \mu \mathrm{m}$. (E-G) Late stages. (E) The nucleus is now located in the outer portion of the oocyte and is kidney-shaped. Scale bar $=150 \mu \mathrm{m}$. (F) The oocyte's nucleus has begun to surround a deep invagination in the plasma membrane and in section appears ' $U$ '-shaped. The ooplasm is full of small yolk plates. Scale bar $=60 \mu \mathrm{m}$. (G) Detail of the nucleus of a mature oocyte. The nucleus uniformly adheres to the invaginated plasma membrane. Location of the nucleolus coincides with the bottom portion of the invagination. Scale bar $=60 \mu \mathrm{m}$. cc: coelenteric cavity; g: gastrodermis; m: mesoglea; mf: mesenteric filament; o: oocyte; N: nucleus; n: nucleolus; ss: skeletal septum; yp: yolk plates; sti: spermatocytes; III: stage of spermary development (see 'Results') 


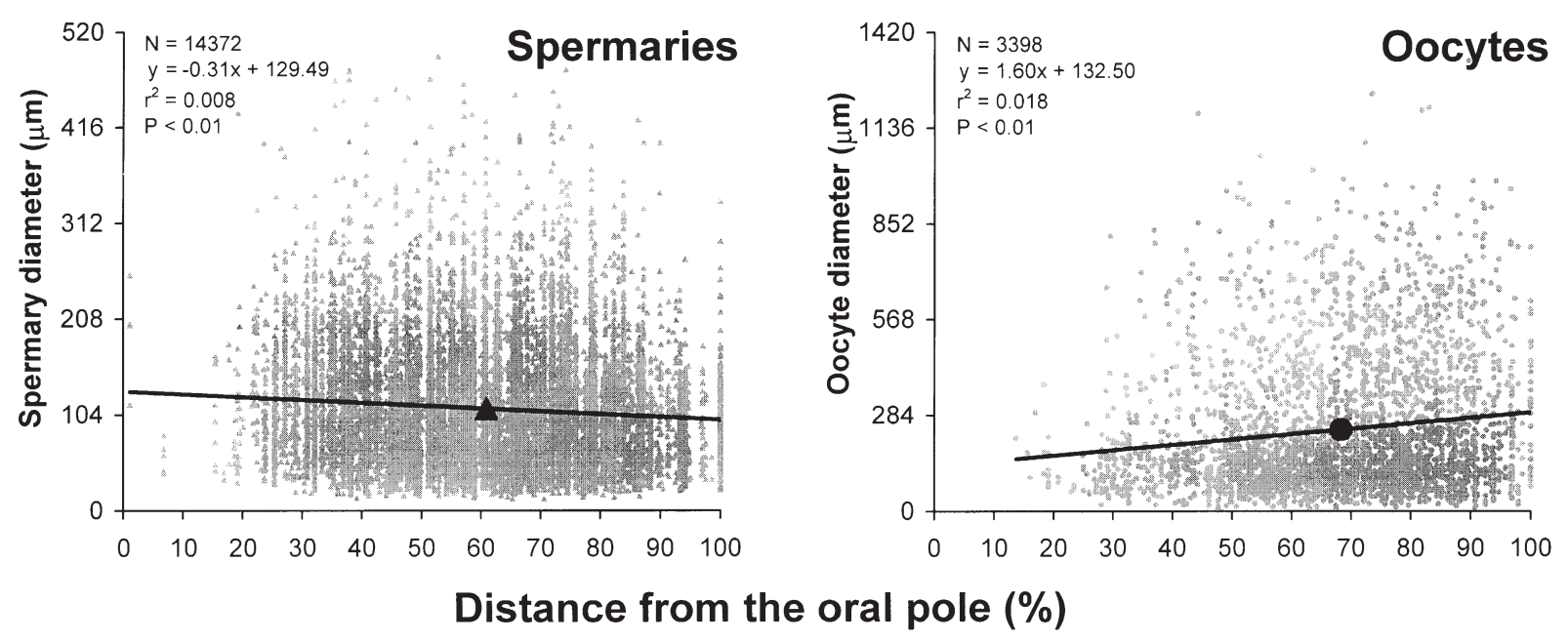

Fig. 4. Balanophyllia europaea. Spermary and oocyte size distribution along the oral-aboral axis of the hermaphroditic polyp. The distance from the oral pole is expressed as a percentage: $0 \%$ is the oral pole level and $100 \%$ the aboral pole level. $\boldsymbol{\Delta}$ : the point at

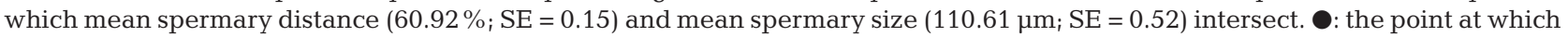
mean oocyte distance $(68.34 \%$; SE $=0.29)$ and mean oocyte size $\left(241.55 \mu m_{i} \mathrm{SE}=3.43\right)$ intersect. Note that the value ranges on the ordinate axes are different
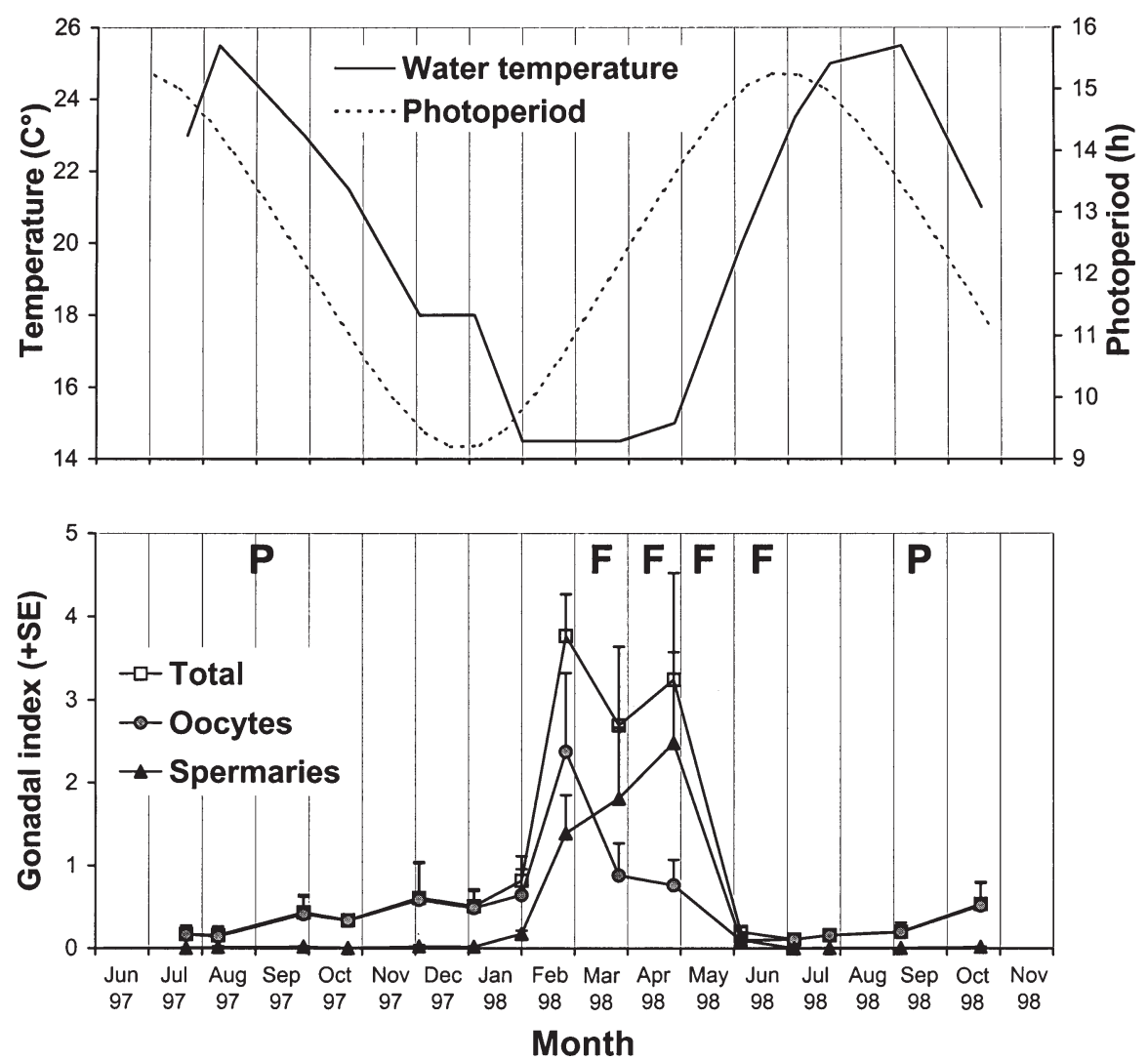

Fig. 5. Balanophyllia europaea. Variation of gonadal development, water temperature and photoperiod for the 16 mo in which samples were collected. Mean length of analyzed mature polyps: $13.93 \mathrm{~mm}(\mathrm{SE}=0.38 ; \mathrm{n}=59)$. $\mathrm{P}=$ planulation period; $\mathrm{F}=$ fertil- 


\section{Oocytes Embryos}

July-97

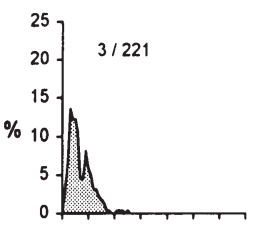

$\mathbf{P}$
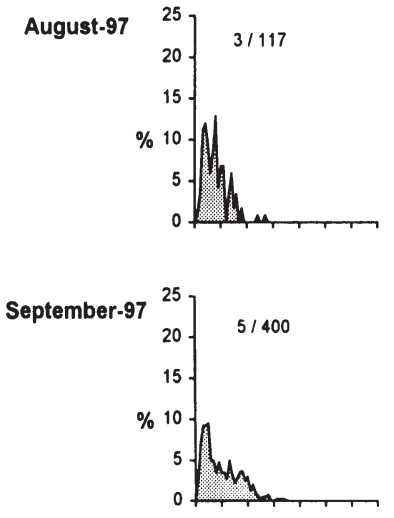

October-97

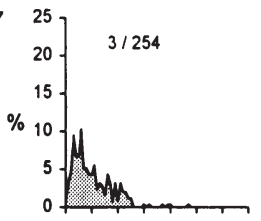

November-97
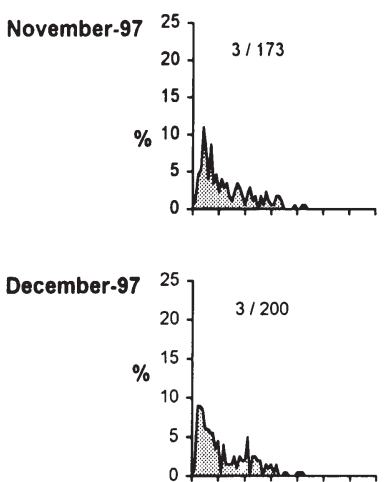

January-98

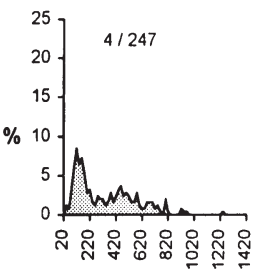

mature

$-$

-

- intermediate, mature
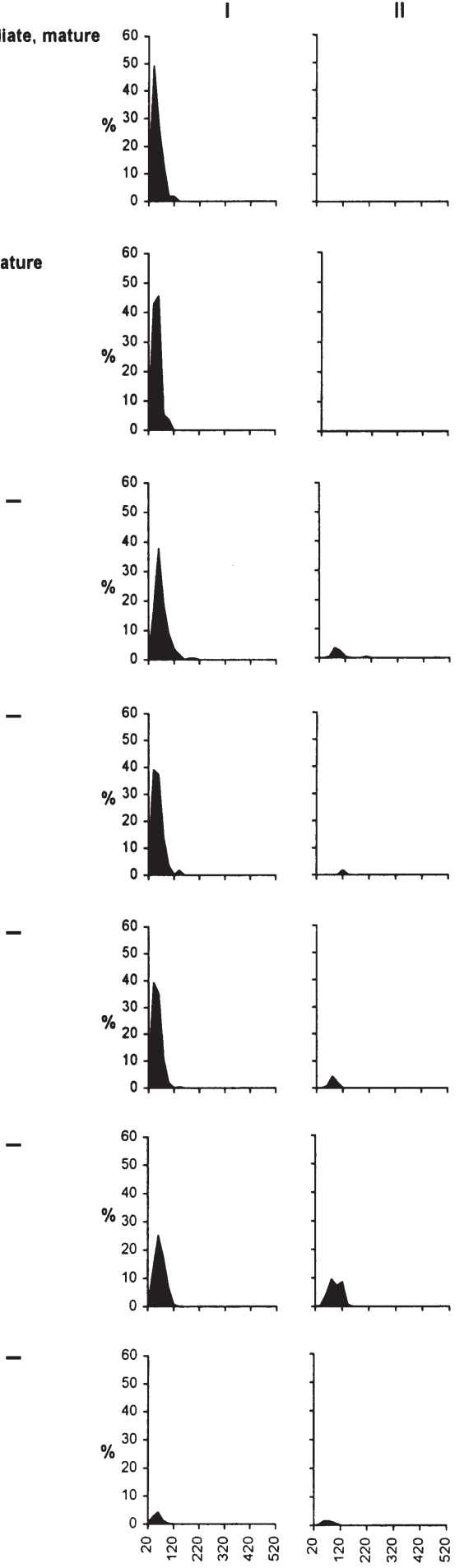
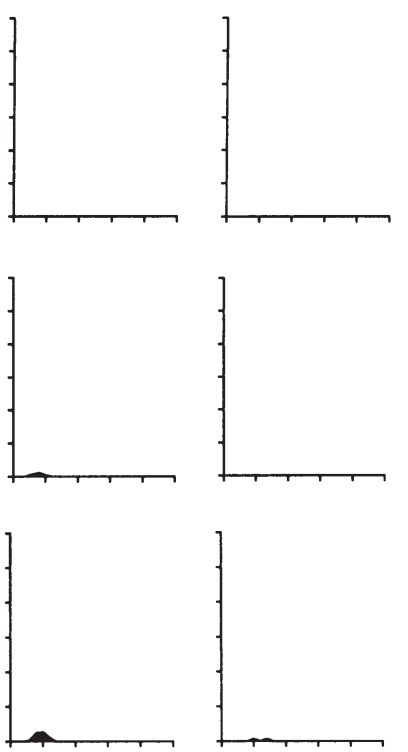

Spermaries
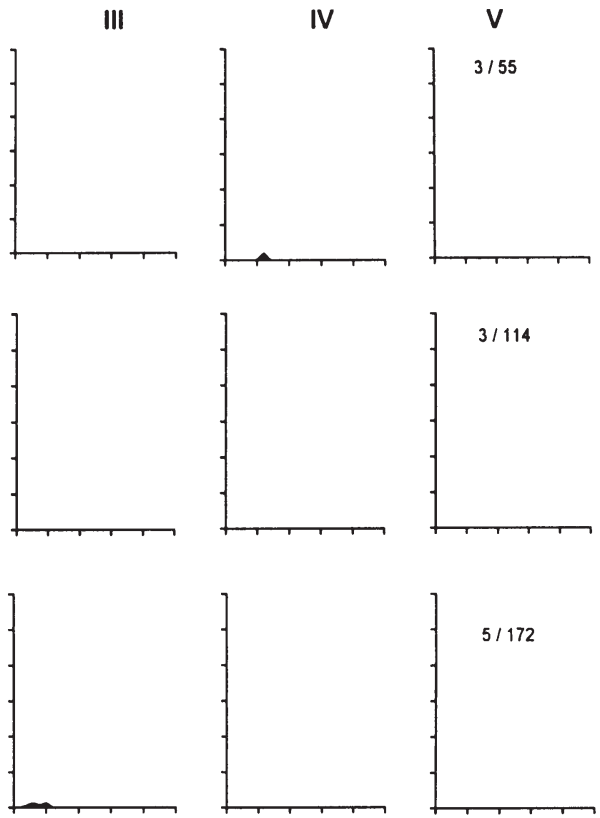

$5 / 172$

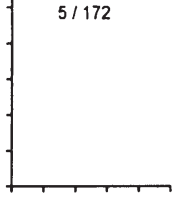

$3 / 59$

$3 / 261$

$3 / 295$

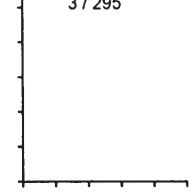

$4 / 866$
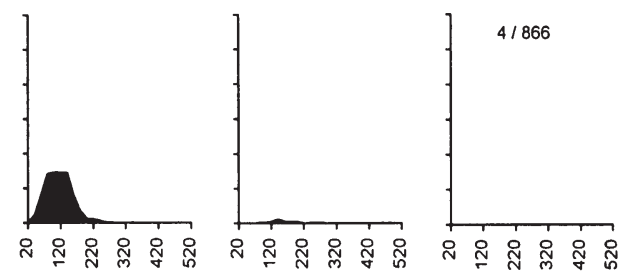

\section{Diameter $(\mu \mathrm{m})$}

Fig. 6. Balanophyllia europaea. Size-frequency distributions of oocyte and of the 5 spermary maturation stages in monthly samples collected off the coast of Calafuria from July 1997 to October 1998. Mean length of analyzed mature polyps: $13.93 \mathrm{~mm}$ (SE = $0.38 ; \mathrm{n}=59$ ). Values reported in the graphs indicate the number of reproductive polyps/total number of oocytes or spermaries measured per monthly sample. The middle column illustrates the presence of embryos in the polyp's coelenteric cavity and their stage of development. $\mathrm{P}=$ planulation period; $\mathrm{F}=$ fertilization period 


\section{Oocytes}

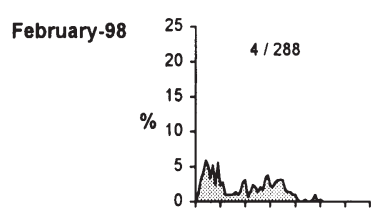

\section{$F$}

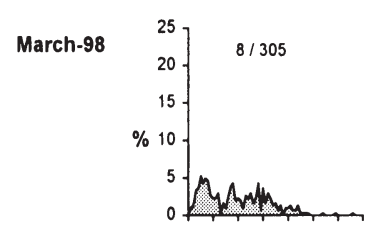

F

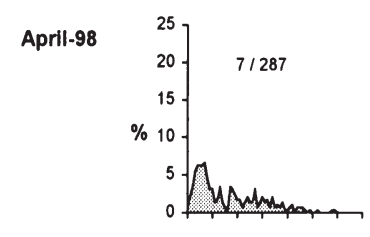

F

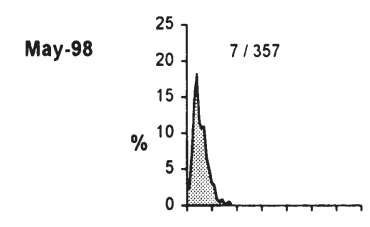

F June-98

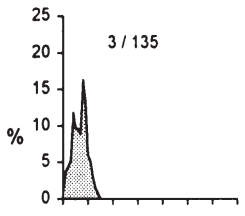

July-98

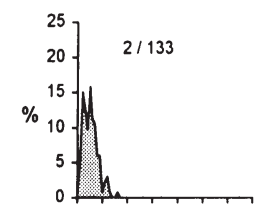

P August-98

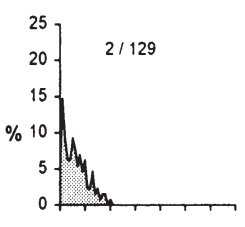

October-98

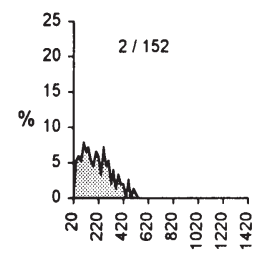

Embryos
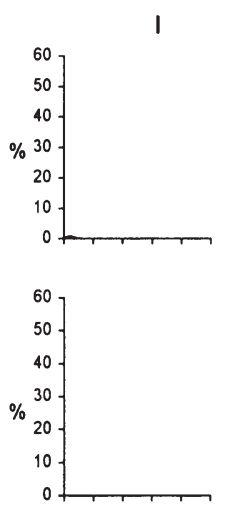

early

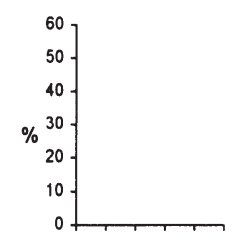

early, intermediate
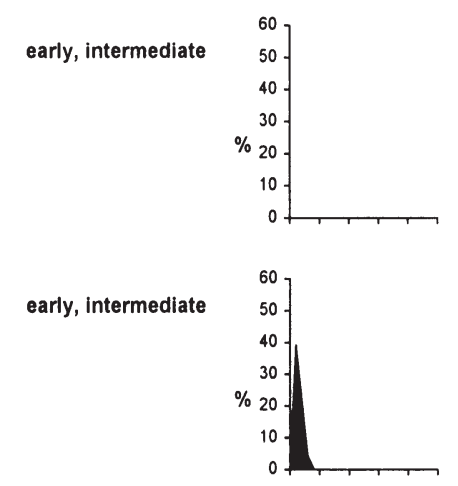

intermediate, mature

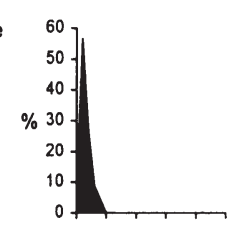

mature

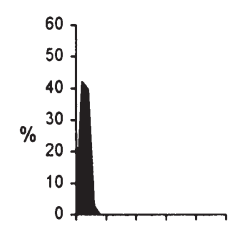

$-$

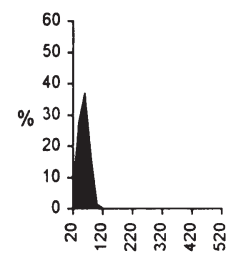

\section{Spermaries}

III
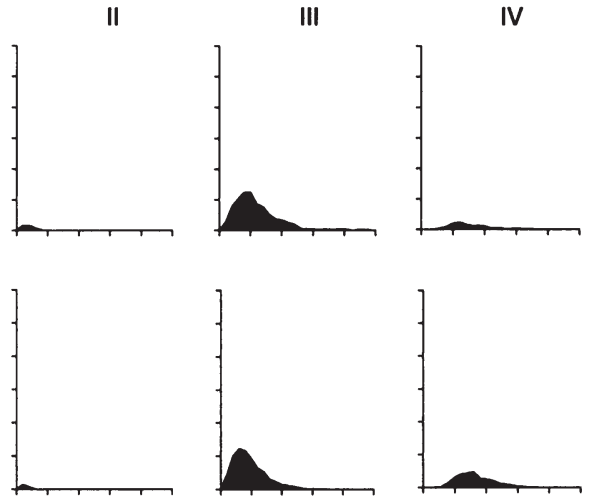

$8 / 4717$
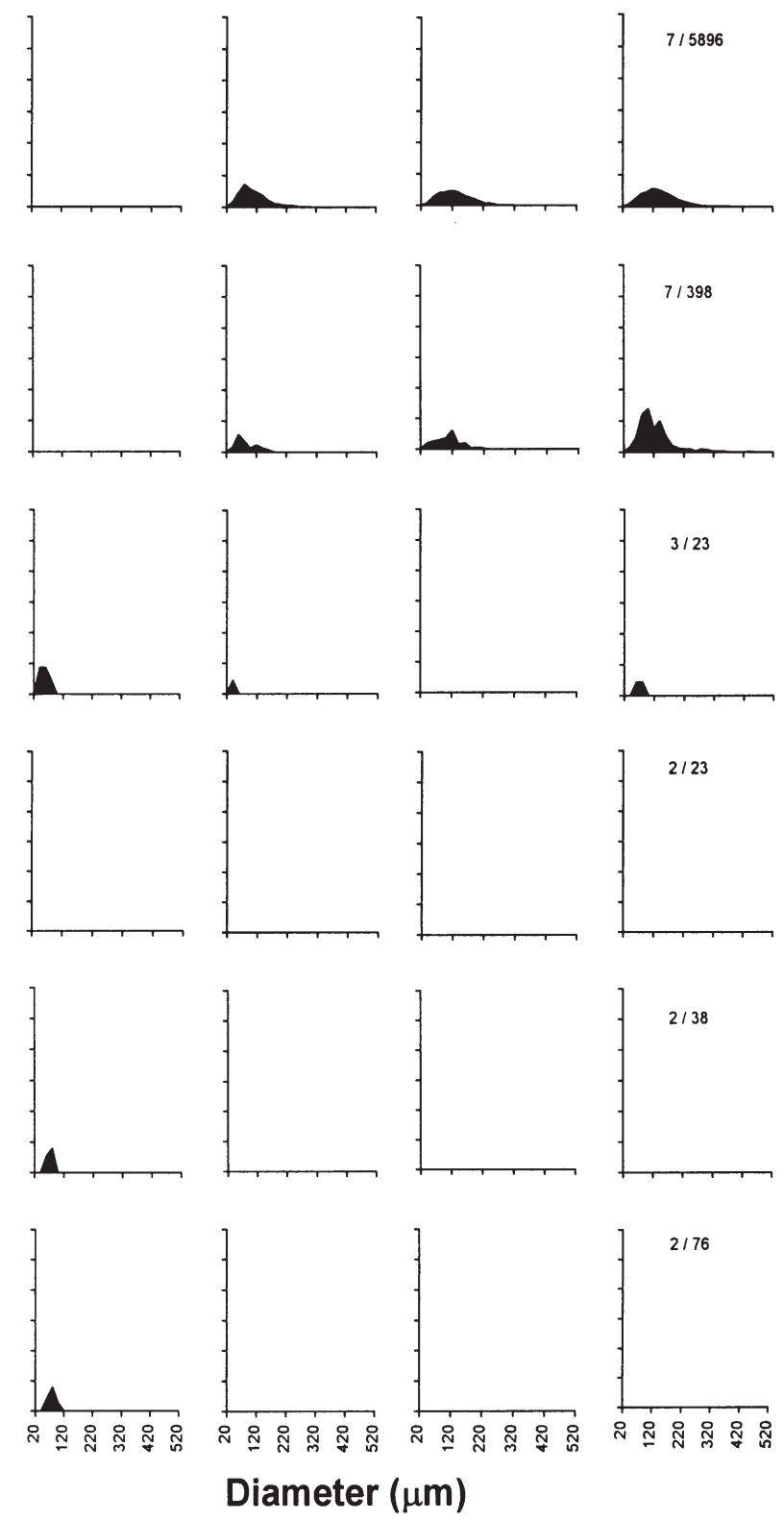

Fig. 6 (continued) 


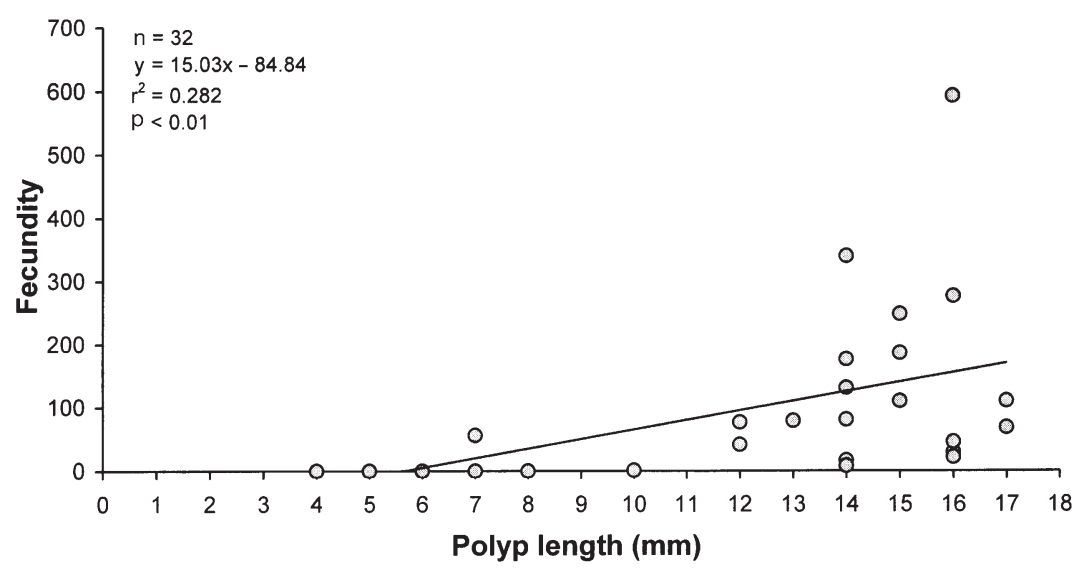

Fig. 7. Balanophyllia europaea. Relationship between fecundity (mature oocytes per polyp) and polyp size of hermaphroditic polyps in the solitary scleractinian coral

water hydrozoans, and anthozoans, are characterized by the presence of nervous cells throughout their entire body; it has been hypothesized that the neurosecretory activity of these cells is responsible for determining the sexual gonad distribution along the polyp's oral-aboral axis (Schaller 1973, Schaller \& Gierer 1973, Stagni 1974). Additional research is needed to highlight sexual determination and differentiation in metazoans characterized by a low level of organization.

A possible functional explanation for the gametic distribution observed along the hermaphroditic polyp's oral-aboral axis could be that the release and diffusion of sperm into the external environment is facilitated by their proximity to the stomodeum. Furthermore, this kind of distrib-

Specimens of $8 \mathrm{~mm}$ in length contained a mean of 8.2 oocytes $(\mathrm{SE}=8.0)$, those $13 \mathrm{~mm}$ in length contained a mean of 124.4 oocytes ( $\mathrm{SE}=28.5)$, and specimens that were $18 \mathrm{~mm}$ in length contained a mean 163.4 oocytes $(\mathrm{SE}=78.7)$.

\section{DISCUSSION}

\section{Polyp size at sexual maturity}

In the studied sample, the size of the polyps of Balanophyllia europaea at sexual maturity was from 6 to $10 \mathrm{~mm}$ in length. According to Goffredo (1999), specimens of this size are approximately $3 \mathrm{yr}$ old. B. elegans reaches sexual maturity at an age close to this one; according to Fadlallah (1983a) individuals reach sexual maturity at approximately $2 \mathrm{yr}$ of age and at 1 to 3 yr of age according to Beauchamp (1993).

\section{Oral-aboral distribution of gametogenic processes}

The observed differential spermary and oocyte distribution could have been caused by the migrations of these reproductive elements towards the oral and aboral poles, respectively; this could occur during their maturation and would explain the overlapping of the more immature elements. The oral-aboral distribution of Balanophyllia europaea gametogenetic processes is in some ways analogous to that found in other hermaphroditic polyps of freshwater hydras (Stagni 1974, Vannini 1974, Grassi et al. 1995), the octocoral Heteroxenia fuscenses (Achituv \& Benayahu 1990) and the scleractinian corals Stylophora pistillata (Rinkevich \& Loya 1979) and Oulastrea crispata (Lam 2000). Fresh- ution could serve as a barrier to self-fertilization by significantly reducing the number of encounters of gametes of the opposite sex produced by the same individual. Future biomolecular analyses, similar to those conducted by Orr et al. (1982) and by Stoddart (1983) may provide information on the genetic relationship between parental polyps and their progeny.

\section{The reproductive cycle}

The size-frequency distribution of the spermaries observed in our monthly samples of Balanophyllia europaea suggests that spermatogenesis follows an annual cycle, and that male germ cells take 12 mo to mature. In contrast, oocyte distribution, which clearly shows the presence of 2 stocks, indicates that female germ cells take approximately 24 mo to mature. The same timing for gamete development was estimated in the only other congeneric species whose reproductive cycle has been studied in detail: B. elegans living in the temperate waters off the coast of California (Fadlallah \& Pearse 1982a, Beauchamp 1993). The longer time required for female germ cells to mature is typical of gametogenesis in anthozoans (Benayahu et al. 1990, Harrison \& Wallace 1990, Richmond \& Hunter 1990, Coma et al. 1995, Fan \& Dai 1995, 1998, Acosta \& Zea 1997, Kramarsky-Winter \& Loya 1998).

Seasonal variation in photoperiod and water temperature appears to play an important role in regulating the annual reproductive cycle in Balanophyllia europaea. Indeed, a significant increase in gonadal development occurs toward January-February, when the photoperiod becomes longer after its annual minimum; fertilization takes place in March to June, the period in which water temperature increases after its annual 
minimum; and the planulae are released towards August-September, when water temperature starts to decrease after its annual peak. The photoperiod and/or water temperature may affect the reproductive cycle in many other anthozoans living in both temperate and tropical waters (Richmond \& Hunter 1990, Soong 1991, Clayton \& Collins 1992, Fadlallah et al. 1992, Beauchamp 1993, Babcock et al. 1994, Coma et al. 1995, Steiner 1995, Fadlallah 1996, Tanner 1996, Acosta \& Zea 1997, Glynn et al. 2000). In B. europaea, an increasing photoperiod during January-February could start gonadal development by increasing photosynthetic rate in symbiont zooxanthellae, thus giving the corals the energy needed to trigger gametogenesis (Rinkevich 1989). Furthermore, the increase and decrease of water temperature in March to June and in August-September, respectively, may serve to trigger fertilization in the former case and planulae release in the latter, so that subsequent dispersion, settlement, and metamorphosis of the larvae as well as the growth of young polyps take place in optimal environmental conditions (Giese \& Pearse 1974, Fadlallah \& Pearse 1982a,b, Beauchamp 1993, Holts \& Beauchamp 1993). Reproduction prior to the onset of autumn and winter may avoid high mortality of young individuals due to adverse conditions, thus allowing greater reproductive success (Fan \& Dai 1995).

Data on annual reproductive cycle were collected for $1.3 \mathrm{yr}$, and thus possible inter-annual variation was not revealed. However, similar stages of the reproductive cycle were observed in the period July to October, which was analyzed both in 1997 and in 1998.

\section{Reproductive strategies}

The diameter of mature oocytes in Balanophyllia europaea was 440 to $1400 \mu \mathrm{m}$, in contrast to 600 to $920 \mu \mathrm{m}$ in B. elegans (Fadlallah \& Pearse 1982a, Beauchamp 1993). In the latter species, small $\left(100 \mathrm{~mm}^{3}\right)$ and large $\left(700 \mathrm{~mm}^{3}\right)$ sexually mature individuals produced a mean of 2 and 40 oocytes, respectively (Fadlallah \& Pearse 1982a, Fadlallah 1983a). Fecundity in same-sized individuals of $B$. europaea was about 2.5 to $3.0 \times$ greater ( 6 mature oocytes per $100 \mathrm{~mm}^{3}$ polyp and 99 mature oocytes per $700 \mathrm{~mm}^{3}$ polyp). Notable differences between the 2 species in embryonic incubation period (4 to $5 \mathrm{mo}$ in $B$. europaea vs 14 to $15 \mathrm{mo}$ in B. elegans: Fadlallah \& Pearse 1982a, Beauchamp 1993), maximum planula size $(2000 \mu \mathrm{m}$ diameter in $B$. europaea; Goffredo \& Telò 1998, vs $3700 \mu \mathrm{m}$ diameter in B. elegans; Gerrodette 1981, Fadlallah \& Pearse 1982a, Beauchamp 1993), may be associated with the above differences in fecundity values. Higher egg production has been directly associated with less parental care of embryos and the production of poorly specialized larvae (Pianka 1970, Loya 1976, Fadlallah \& Pearse 1982b). Higher fecundity, shorter embryonic incubation, and the smaller size of larvae in B. europaea compared to $B$. elegans, in addition to hermaphroditism versus gonochorism, would seem to place the reproductive strategies of the former species towards the $r$ endpoint and the latter's towards the $K$ endpoint on the $r$-K continuum (Pianka 1970, Kramarsky-Winter \& Loya 1998). Future studies on population dynamics in $B$. europaea could be compared to those done on $B$. elegans (Gerrodette 1979, Fadlallah 1983a) and could help to further define the life history strategies of these congeneric species.

Acknowledgements. This study was supported by grants from the Scuba Schools International Italia, the Italian Ministry for University and Scientific and Technological Research, and sponsored by the Underwater Life Project. We wish to thank Prof. Franca Scanabissi for her contribution in morphological techniques; Prof. Barbara Mantovani for her valuable revision of the text; Dr Rosanna Falconi for her advice on laboratory techniques; Dr Tiziana Telò for conducting the first histological tests; the Bologna Scuba Team for its logistical and practical support for the dives; the divers Mario Pasquini, Claudia Ronzani, Sandra Tassinari, Riccardo Zanasi, Sabina Scifo, Luisella Riva, Mirko Spoto, Monica Nanni, Monica Forni and Paolo Bergami for the assistance in the collection of monthly samples, and the Marine Science Group for organizing and supervising the dives.

\section{LITERATURE CITED}

Achituv Y, Benayahu Y (1990) Polyp dimorphism and functional, sequential hermaphroditism in the soft coral Heteroxenia fuscescens (Octocorallia). Mar Ecol Prog Ser 64: 263-269

Acosta A, Zea S (1997) Sexual reproduction of the reef coral Montastrea cavernosa (Scleractinia: Faviidae) in the Santa Marta area, Caribbean coast of Colombia. Mar Biol 128: $141-148$

Aleem AA, Aleem EAA (1992) Balanophyllia europaea (Risso, 1826): a scleractinian solitary coral in the southeastern Mediterranean. J Egypt Gen Soc Zool 8:227-233

Babcock RC, Bull GD, Harrison PL, Heyward AJ, Oliver JK, Wallace CC, Willis BL (1986) Synchronous spawning of 105 scleractinian coral species on the Great Barrier Reef. Mar Biol 90:379-394

Babcock RC, Willis BL, Simpson CJ (1994) Mass spawning of corals on high latitude coral reef. Coral Reefs 13:161-169

Bacci G (1975) Genetic and environmental controls of sex determination in marine animals. Pubbl Stn Zool Napoli 39:366-376

Beauchamp KA (1993) Gametogenesis, brooding and planulation in laboratory populations of a temperate scleractinian coral Balanophyllia elegans maintained under contrasting photoperiod regimes. Invert Repr Dev 23:171-182

Benayahu Y, Weil D, Kleinman M (1990) Radiation of broadcasting and brooding patterns in coral reef alcyonaceans. In: Hoshi M, Yamashita O (eds) Advances in invertebrate reproduction. Elsevier Science Publishers BV (Biomed. Div.), Amsterdam, p 323-328 
Bianchini M, Di Stefano L, Ragonese S (1998) Size and age at onset of sexual maturity of female Norway lobster Nephrops norvegicus L. (Crustacea: Nephropidae) in the Strait of Sicily (Central Mediterranean Sea). Sci Mar 62:151-159

Cairns DS (1977) Biological results of the University of Miami deep-sea expedition. 121. A review of the recent species of Balanophyllia (Anthozoa: Scleractinia) in the western Atlantic, with descriptions of four new species. Proc Biol Soc Wash 90:132-148

Clayton PD, Collins DJ (1992) Reproduction and feeding ethology of a tropical, intertidal sand-dwelling anemone (Actinoporus elongatus, Carlgren, 1900). Hydrobiologia 237:31-38

Coma R, Ribes M, Cabala M, Gili JM (1995) Reproduction and cycle of gonadal development in the Mediterranean gorgonian Paramuricea clavata. Mar Ecol Prog Ser 117: 173-183

Fadlallah YH (1983a) Population dynamics and life history of a solitary coral, Balanophyllia elegans, from Central California. Oecologia 58:200-207

Fadlallah YH (1983b) Sexual reproduction, development and larval biology in scleractinian corals: a review. Coral Reefs 2:129-150

Fadlallah YH (1996) Synchronous spawning of Acropora clathrata coral colonies from the western Arabian Gulf (Saudi Arabia). Bull Mar Sci 59:209-216

Fadlallah YH, Pearse JS (1982a) Sexual reproduction in solitary corals: overlapping oogenic and brooding cycles, and benthic planulas in Balanophyllia elegans. Mar Biol 71: 223-231

Fadlallah YH, Pearse JS (1982b) Sexual reproduction in solitary corals: synchronous gametogenesis and broadcast spawning in Paracyathus stearnsii. Mar Biol 71:233-239

Fadlallah YH, Lindo RT, Lennon DJ (1992) Annual synchronous spawning event in Acropora species for the western Arabian Gulf. Proc 7th Int Coral Reef Symp Guam 1:501

Fan TY, Dai CF (1995) Reproductive ecology of the scleractinian coral Echinopora lamellosa in northern and southern Taiwan. Mar Biol 123:565-572

Fan TY, Dai CF (1998) Sexual reproduction of the scleractinian coral Merulina ampliata in southern Taiwan. Bull Mar Sci 62:897-904

Fautin DG (1992) Cnidaria. In: Adiyodi KJ, Adiyodi RG (eds) Reproductive biology of invertebrate, Vol. 5. Sexual differentiation and behaviour. John Wiley \& Sons, New York, p 31-52

Gerrodette T (1979) Ecological studies of two temperate solitary corals. PhD thesis, University of California, San Diego

Gerrodette T (1981) Dispersal of the solitary coral Balanophyllia elegans by demersal planular larvae. Ecology (Wash) 62:611-619

Giese AC, Pearse JS (1974) Introduction: general principles. In: Giese AC, Pearse JS (eds) Reproduction of marine invertebrates. I. Acoelomate and pseudocoelomate metazoans. Academic Press, New York, p 1-49

Glynn PW, Colley SB, Ting JH, Maté JL, Guzman HM (2000) Reef coral reproduction in the eastern Pacific: Costa Rica, Panama and Galapagos Islands (Ecuador). IV. Agariciidae, recruitment and recovery of Pavona varians and Pavona sp.a. Mar Biol 136:785-805

Goffredo S (1999) Population dynamics and reproductive biology of the solitary coral Balanophyllia europaea (Anthozoa, Scleractinia) from the Northern Tyrrhenian Sea. PhD thesis, University of Bologna

Goffredo S, Telò T (1998) Hermaphroditism and brooding in the solitary coral Balanophyllia europaea (Cnidaria, Anthozoa, Scleractinia). Ital J Zool 65:159-165
Goffredo S, Telò T, Scanabissi F (2000) Ultrastructural observations of the spermatogenesis of the hermaphroditic solitary coral Balanophyllia europaea (Anthozoa, Scleractinia). Zoomorphology (Berl) 119:231-240

Grassi M, Tardent R, Tardent P (1995) Quantitative data about gametogenesis and embryonic development in Hydra vulgaris Pall (Cnidaria, Hydrozoa). Invert Reprod Develop 27:219-232

Hall VR, Hughes TP (1996) Reproductive strategies of modular organisms: comparative studies of reef-building corals. Ecology (Wash) 77:950-963

Harrison PL (1985) Sexual characteristics of scleractinian corals: systematic and evolutionary implications. Proc 5th Int Coral Reef Symp Tahiti 4:337-342

Harrison PL, Wallace CC (1990) Reproduction, dispersal and recruitment of scleractinian corals. In: Dubinsky Z (ed) Ecosystem of the world. 25. Coral reefs. Elsevier, Amsterdam, p 133-207

Holts LJ, Beauchamp KA (1993) Sexual reproduction in the corallimorpharian sea anemone Corynactis californica in a central California kelp forest. Mar Biol 116:129-136

Kramarsky-Winter E, Loya Y (1998) Reproductive strategies of two fungiid corals from the northern Red Sea: environmental constraints? Mar Ecol Prog Ser 174:175-182

Kruger A, Schleyer MH (1998) Sexual reproduction in the coral Pocillopora verrucosa (Cnidaria: Scleractinia) in KwaZulu-Natal, South Africa. Mar Biol 132:703-710

Lacaze-Duthiers H (1873) Développment des coralliaires. Actinaires à Polypiers. Arch Zool Exp Gén 2:269-348

Lacaze-Duthiers H (1897) Faune du Golfe du Lion. Coralliaires, Zooanthaires, Sclérodermés. Arch Zool Exp Gén 5: $1-249$

Lam KKY (2000) Sexual reproduction of a low-temperature tolerant coral Oulastrea crispata (Scleractinia, Faviidae) in Hong Kong, China. Mar Ecol Prog Ser 205:101-111

Loya Y (1976) The red sea coral Stylophora pistillata is an $\mathrm{r}$ strategist. Nature 259:478-480

Oh CW, Hartnoll RC (1999) Size at sexual maturity, reproductive output, and seasonal reproduction of Philocheras trispinosus (Decapoda) in Port Erin Bay, Isle of Man. J Crustac Biol 19:252-259

Oliver JK, Babcock RC, Harrison PL, Willis BL (1988) Geographic extent of mass coral spawning: clues to ultimate causal factors. Proc 6th Int Coral Reef Symp Townsville 2: $803-810$

Orr J, Thorpe JP, Carter MA (1982) Biochemical genetical confirmation of the asexual reproduction of brooded offspring in the sea anemone Actinia equina. Mar Ecol Prog Ser 7:227-222

Pianka ER (1970) On r- and K- selection. Am Nat 104: 592-597

Richmond RH (1997) Reproduction and recruitment in corals: critical links in the persistence of reefs. In: Birkeland C (ed) Life and death of coral reefs. Chapman \& Hall Inc., New York, p 175-197

Richmond RH, Hunter CL (1990) Reproduction and recruitment of corals: comparisons among the Caribbean, the tropical Pacific, and the Red Sea. Mar Ecol Prog Ser 60: 185-203

Rinkevich B (1989) The contribution of photosynthetic products to coral reproduction. Mar Biol 101:259-263

Rinkevich B, Loya Y (1979) The reproduction of the Red Sea coral Stylophora pistillata. I. Gonads and Planulae. Mar Ecol Prog Ser 1:133-144

Roa R, Ernst B, Tapia F (1999) Estimation of size at sexual maturity; an evaluation of analytical and resampling procedures. Fish Bull US 3:570-580 
Rossi L (1975) Sexual races in Cereus pedunculatus (Boad). Publ Stn Zool Napoli 39:462-470

Schaller H (1973) Isolation and characterization of a lowmolecular-weight substance activating head and bud formation in Hydra. J Embryol Exp Morphol 29:27-28

Schaller H, Gierer A (1973) Distribution of head-activating substance in Hydra and its localization in membranous particles in nerve cells. J Embryol Exp Morphol 29:39-52

Schumacher H, Zibrowius H (1985) What is hermatypic? A redefinition of ecological groups in corals and other organisms. Coral Reefs 4:1-9

Shaw PW (1989) Seasonal patterns and possible long-term effectiveness of sexual reproduction in three species of sagartiid sea anemones. In: Ryland JS, Tyler PA (eds) Reproduction, genetics and distributions of marine organisms. Olsen \& Olsen, Fredensborg, p 189-199

Soong K (1991) Sexual reproductive patterns of shallowwater reef corals in Panama. Bull Mar Sci 49:832-846

Stagni A (1974) Some aspects of sexuality in fresh-water hydras. Boll Zool 41:349-358

Steiner SCC (1995) Spawning in scleractinian corals from SW Puerto Rico (West Indies). Bull Mar Sci 56:899-902

Stoddart JA (1983) Asexual production of planulae in the coral Pocillopora damicornis. Mar Biol 76:279-284

Stoddart JA, Black R (1985) Cycles of gametogenesis and planulation in the coral Pocillopora damicornis. Mar Ecol Prog Ser 23:153-164

Editorial responsibility: Otto Kinne (Editor),

Oldendorf/Luhe, Germany
Szmant AM (1986) Reproductive ecology of Caribbean reef corals. Coral Reefs 5:43-53

Tanner JE (1996) Seasonality and lunar periodicity in the reproduction of pocilloporid corals. Coral Reefs 15:59-66

Tomascik T, Sander F (1987) Effects of eutrophication on reefbuilding corals. III. Reproduction of the reef-building coral Porites porites. Mar Biol 94:77-94

Van Moorsel GWNM (1983) Reproductive strategies in two closely related stony corals (Agaricia, Scleractinia). Mar Ecol Prog Ser 13:273-283

Vannini E (1974) Introduction to the symposium. Boll Zool 41: 291-326

Ward S (1992) Evidence for broadcast spawning as well as brooding in the scleractinian coral Pocillopora damicornis. Mar Biol 112:641-646

Yoneda M, Tokimura M, Fujita H, Takeshita N, Takeshita $\mathrm{K}$, Matsuyama M, Matsuura S (1998) Reproductive cycle and sexual maturity of the anglerfish Lophiomus setigerus in the East China Sea with a note on specialized spermatogenesis. J Fish Biol 53:164-178

Zibrowius H (1980) Les scléractiniaires de la Méditerranée et de l'Atlantique nord-oriental. Mem Inst Oceanogr (Monaco) 11:1-284

Zibrowius H (1983) Nouvelles données sur la distribution de quelques scléractiniaires 'méditerranéens' à l'est et à l'ouest du détroit de Gibraltar. Rapp Comm Int Mer Médit 28:307-309

Submitted: March 7, 2001; Accepted: July 31, 2001

Proofs received from author(s): February 27, 2002 